\title{
INCOME DIVERSIFICATION AND BANK PERFORMANCE: THE JORDANIAN CASE
}

\author{
DOI: 10.17261/Pressacademia.2019.1013 \\ JBEF- V.8-ISS.1-2019(3)-p.28-37
}

\section{Ghassan Omet}

University of Jordan, Amman, Jordan.

gomet@ju.edu.jo, ORCID: 0000-0002-0163-1387

Date Received: January 20, 2019

Date Accepted: March 6, 2019

To cite this document

Omet, G. (2019). Income diversification and bank performance: The Jordanian case. Journal of Business, Economics and Finance (JBEF), V.8(1), p.28-37.

Permemant link to this document: $\underline{\text { http://doi.org/10.17261/Pressacademia.2019.1013 }}$

Copyright: Published by PressAcademia and limited licenced re-use rights only.

\begin{abstract}
Purpose - The purpose of this paper is to examine Jordanian banks in terms of the impact of income diversification on their performance (profitability and net interest margin).

Methodology - Based on the period 2009-2017 and all thirteen Jordanian commercial banks, the econometric models are estimated using the Seemingly Unrelated Regression (SUR). Bank performance is measured by return on assets and net interest margin. As far as banks' income diversification is concerned, we use a myriad of measures including net commission income to total assets, proportion of bank credit to individuals, SME sector, corporate sector to total credit, and the real estate sector.

Findings - Based on the statistical analyses, we conclude that that income diversification impacts bank profitability in a positive manner. However, this impact (positive) comes only at the expense of widening net interest margins.

Conclusion - It is in the interest of the banking system in Jordan to promote financial inclusion at the national level. Indeed, this aspect is important to, not only the concerned individuals, but also to their (banks) performance. Moreover, with greater levels of financial inclusion, net interest margin might also narrow.
\end{abstract}

Keywords: Financial development, dollarization, net-interest margin, return on assets, financial inclusion.

JEL Codes: G20, G21, G24

\section{INTRODUCTION}

The economic importance of financial systems has led to the publication of numerous theoretical and empirical papers. However, the classical aspect of this literature is not conclusive. Back in 1873, Bagehot, for example, argued that the financial system mobilized the necessary capital for England's industrialization. Joan Robinson (1952), on the other hand, argued that it is businesses and economic growth lead finance. Within this context, Lucas (1988) argued that the interplay between finance and economic growth, on average, is overstressed. Nobody can deny that banks, as well as stock markets, provide economies with a myriad of economically useful financial services. Indeed, banks "facilitate the trading, hedging, diversifying, and pooling of risk, allocate resources, monitor managers and exert corporate control, mobilize savings, and facilitate the exchange of goods and services" (Levine, 1997).

Given the economic implications of financial systems, the World Bank publishes the Global Financial Development Database. This database provides researchers with annual financial system characteristics for more than 200 economies since 1960. The characterizations (109 in total) include measures of financial depth, financial access, financial efficiency, and financial stability. Following the publication of the classical theoretical models of Ho and Saunders (1981), Allen (1988), and Angbazo (1997), numerous empirical papers looked at the profitability (return on assets) aspect and cost of intermediation (net interest margin) of banks.

The empirical side of this literature, on average, regresses bank profitability and net interest margin on a number of variables that include bank-specific variables, banking-sector variables, and macroeconomic variables.

*The Author wishes to thank the University of Jordan for the sabbatical year 2017/2018 and during which this research was prepared. 
Some of the more recent papers that examine country-level bank performances include Almarzoqi and Ben Naceur (2015), Nassar et al (2015), Helhel (2015), Catao et al. (2016), Hashem (2016), Jima (2018), Kohlscheen et al. (2018), and others. Within the context of the subject matter of banks' performance, the impact of their income diversification has caught some special attention.

Again, the theoretical impact of income diversification on bank performance is not conclusive. It is argued that more diversification results in superior performance (Klein and Saidenberg, 1997). In other words, if the sources of income (diversified) are not perfectly correlated, they would result in more stable and higher profits (Chiorazzo et al., 2008). On the other hand, if the diversified activities are riskier, they might make banks' balance sheets riskier and deteriorate performance (Boyd et al., 1993).

The empirical literature that examines the impact of income diversification on bank performance, as one might expect, is also not conclusive. In other words, it is really an empirical issue. For example, Berger et al. (2010) examined a panel of 88 Chinese banks during the period 1996-2006 and found that diversification (non-interest income) results in lower profits.

Similarly, Maudos (2017) report that increases in the share of non-interest income to total income has a negative effect on profitability. In contrast, Elsas et al. (2010), using banking data from Australia, Canada, France, Germany, Italy, UK, US, Spain and Switzerland, show that diversification improves bank profitability. This finding (positive impact) is also supported by the findings of Nisar et al. (2018) who examined a total of 200 commercial banks in South Asia over the period 2000-2014.

Within the context of the interplay between income diversification and bank performance, it is interesting to note that other researchers have used different measures of income diversification. For example, Adzobu et al. (2017) examine whether diversification of credit portfolios across economic sectors result in higher profitability and lower credit risks for a panel of 30 Ghanaian banks (2007-2014). The results indicate that loan portfolio diversification does not improve profitability nor does it reduce credit risks (non-performing loans). Within the same spirit, using pooled, fixed, random and System GMM analysis (2006-2013) of 250 commercial banks in 30 Sub-Saharan countries, it is reported that diversification of operational activities impact (positively) their financial performance (Olarewaju et al., 2017).

Relative to the above-mentioned arguments and observations, this paper contributes to the ongoing research on the benefits of bank revenue diversification. Indeed, this is important, not only because banks in Jordan, as far as the researcher is aware, have not been investigated in terms of this issue (sectoral diversification of income sources), but also for two additional reasons.

First, relative to the size of the Jordanian economy, the banking system is large. Licensed banks' 2017 assets are equivalent to about 173 percent of Gross Domestic Product (GDP). Second, Jordanian banks differ significantly in terms of various measures that are important in their respective income diversification. These measures include commission income, ratio of credit to individuals, corporate, real estate, and SMEs to total credit, and proportion of each bank's investment in fixedincome government securities to total assets. The rest of the paper is organized as follows. In section II, we provide some basic information about the Jordanian commercial banks. In section III, we discuss the data and methodology, and present and discuss the empirical results. Finally, section $\mathrm{V}$ summarizes and concludes the paper.

\section{THE JORDANIAN BANKING SECTOR: SOME INFORMATION}

Currently, licensed banks in Jordan are composed of thirteen national banks (commercial), three Islamic banks, and nine foreign banks (commercial). As stated in the introduction, relative to the size of the national economy, the Jordanian banking sector is large. The total assets of all licensed banks are equivalent to more than 170 percent of GDP (Table 1).

This ratio is larger than that in, for example, Poland (around 60 percent), Saudi Arabia (around 95 percent), and comparable to the 190 percent that prevails in Japan (World Bank database). Similarly, total deposits and total credit facilities have surpassed the 100 percent and 80 percent of GDP respectively by the end of 2017 .

Table 1: Size of Licensed Banks in Jordan Relative to Economy

\begin{tabular}{|l|l|l|l|}
\hline Year & Total Assets / GDP & Total Deposits / GDP & Total Credit / GDP \\
\hline 2010 & $186.4 \%$ & $119.9 \%$ & $77.0 \%$ \\
\hline 2011 & $184.0 \%$ & $119.1 \%$ & $77.4 \%$ \\
\hline 2012 & $178.8 \%$ & $113.7 \%$ & $81.1 \%$ \\
\hline 2013 & $179.5 \%$ & $115.7 \%$ & $79.4 \%$ \\
\hline 2014 & $176.4 \%$ & $119.0 \%$ & $75.8 \%$ \\
\hline 2015 & $176.9 \%$ & $122.4 \%$ & $79.2 \%$ \\
\hline 2016 & $176.3 \%$ & $119.9 \%$ & $83.5 \%$ \\
\hline 2017 & $172.6 \%$ & $116.7 \%$ & $87.0 \%$ \\
\hline
\end{tabular}


Licensed banks in Jordan can be commented on in terms of a number of characteristics. These are outlined below. First, foreign exchange deposits constitute a significant proportion of total deposits. In 2017, for example, these deposits constituted about 23 percent of total deposits (Table 2). In other words, one can argue that the banking system in Jordan is dollarized.

Table 2: Bank Deposits in Jordan According to Currency

\begin{tabular}{|l|l|l|}
\hline Year & Local Currency & Foreign Currencies \\
\hline 2010 & $78.3 \%$ & $21.7 \%$ \\
\hline 2011 & $78.4 \%$ & $21.6 \%$ \\
\hline 2012 & $70.9 \%$ & $29.1 \%$ \\
\hline 2013 & $76.1 \%$ & $23.9 \%$ \\
\hline 2014 & $79.4 \%$ & $20.6 \%$ \\
\hline 2015 & $79.8 \%$ & $20.2 \%$ \\
\hline 2016 & $78.9 \%$ & $21.1 \%$ \\
\hline 2017 & $77.2 \%$ & $22.8 \%$ \\
\hline Source: Central Bank of Jordan \\
\hline
\end{tabular}

Second, the construction, individuals (retail), general trade, and the industrial sectors account for the largest shares in terms of their respective credit allocation. For example, 23.1 percent of total banks' credit facilities are allocated to the retail end of the market (Figure 3 ).

Table 3: Sectoral Distribution of Bank Credit

\begin{tabular}{|l|l|l|l|l|l|}
\hline Year & Trade & Construction & Individuals & Industry & Other \\
\hline 2010 & $24.9 \%$ & $21.9 \%$ & $21.4 \%$ & $13.3 \%$ & $18.5 \%$ \\
\hline 2011 & $23.8 \%$ & $21.9 \%$ & $21.5 \%$ & $14.5 \%$ & $18.3 \%$ \\
\hline 2012 & $21.1 \%$ & $20.7 \%$ & $21.5 \%$ & $14.1 \%$ & $22.6 \%$ \\
\hline 2013 & $20.8 \%$ & $21.6 \%$ & $21.9 \%$ & $14.0 \%$ & $21.8 \%$ \\
\hline 2014 & $19.1 \%$ & $23.6 \%$ & $23.3 \%$ & $13.1 \%$ & $20.8 \%$ \\
\hline 2015 & $18.4 \%$ & $23.2 \%$ & $24.6 \%$ & $10.2 \%$ & $23.6 \%$ \\
\hline 2016 & $17.8 \%$ & $25.4 \%$ & $23.5 \%$ & $9.6 \%$ & $23.7 \%$ \\
\hline 2017 & $17.1 \%$ & $26.7 \%$ & $21.3 \%$ & $11.0 \%$ & $23.9 \%$ \\
\hline \multicolumn{2}{l}{ Source: Central Bank of Jordan } & \\
\hline
\end{tabular}

Third, in 2017, Jordanian banks' credit to the private sector was equivalent to 72 percent of GDP. This ratio is relatively low (Table 4).

Table 4: Bank Credit to the Private Sector to GDP Ratio

\begin{tabular}{|l|l|l|l|l|l|}
\hline Country & Ratio & Country & Ratio & Country & Ratio \\
\hline Lebanon & $39.7 \%$ & Qatar & $76.5 \%$ & Turkey & $128.7 \%$ \\
\hline Egypt & $41.0 \%$ & Kenya & $88.5 \%$ & Australia & $131.6 \%$ \\
\hline Algeria & $41.3 \%$ & UAE & $89.8 \%$ & Tunisia & $132.8 \%$ \\
\hline Japan & $47.0 \%$ & Bahrain & $90.4 \%$ & Saudi Arabia & $134.9 \%$ \\
\hline Palestine & $50.1 \%$ & Indonesia & $93.2 \%$ & Georgia & $140.3 \%$ \\
\hline Ghana & $70.7 \%$ & Poland & $96.6 \%$ & Finland & $143.8 \%$ \\
\hline Jordan & $72.4 \%$ & Malaysia & $96.6 \%$ & Chile & $150.0 \%$ \\
\hline Morocco & $74.1 \%$ & Germany & $97.0 \%$ & Portugal & $152.3 \%$ \\
\hline Czech Rep. & $74.2 \%$ & Slovenia & $98.7 \%$ & Sweden & $199.6 \%$ \\
\hline India & $76.2 \%$ & Switzerland & $100.4 \%$ & Denmark & $319.7 \%$ \\
\hline Source: World Bank Database & \\
\hline
\end{tabular}

Fourth, financial inclusion in Jordan is relatively low. For example, the prevailing 42 percent is much lower than those that exist in Denmark (100 percent), UAE (88 percent), and in Turkey (69 percent). 
Table 5: Financial Inclusion

\begin{tabular}{|l|l|l|l|l|l|}
\hline & & & & & \\
\hline Denmark & $100 \%$ & China & $80 \%$ & Jordan & $42 \%$ \\
\hline Germany & $99 \%$ & Chile & $74 \%$ & Tunisia & $37 \%$ \\
\hline UK & $96 \%$ & Saudi Arabia & $72 \%$ & Egypt & $33 \%$ \\
\hline USA & $93 \%$ & Turkey & $69 \%$ & Morocco & $29 \%$ \\
\hline UAE & $88 \%$ & Bangladesh & $50 \%$ & Iraq & $23 \%$ \\
\hline Bahrain & $83 \%$ & Lebanon & $45 \%$ & Afghanistan & $15 \%$ \\
\hline \multicolumn{5}{l}{ Source: World Bank Database } \\
\hline
\end{tabular}

Finally, and to put licensed banks in Jordanian in terms of their international counterparts, we report below (Tables 6-9) some of the main ratios that measure banks' soundness. These include bank regulatory capital to risk-adjusted assets, nonperforming loans to total gross loans, Z-score ((ROA + (equity / assets)) / Standard Deviation of ROA), where ROA refers to gross profit divided by total assets, equity is equity capital, and return on assets.

Table 6: Performance of Banks: Bank Regulatory Capital to Risk-Adjusted Assets

\begin{tabular}{|l|l|l|l|l|l|}
\hline Country & Ratio & Country & Ratio & Country & Ratio \\
\hline India & $12.8 \%$ & Lebanon & $16.3 \%$ & Germany & $18.8 \%$ \\
\hline Chile & $13.4 \%$ & Cyprus & $16.6 \%$ & Belgium & $18.8 \%$ \\
\hline Australia & $14.0 \%$ & Greece & $16.8 \%$ & Saudi Arabia & $19.3 \%$ \\
\hline USA & $14.3 \%$ & Switzerland & $17.2 \%$ & UK & $20.3 \%$ \\
\hline Korea & $14.4 \%$ & W. Bank \& Gaza & $17.6 \%$ & Denmark & $20.8 \%$ \\
\hline Canada & $14.6 \%$ & Czech Rep. & $17.8 \%$ & Latvia & $21.0 \%$ \\
\hline Spain & $15.0 \%$ & Austria & $17.8 \%$ & Finland & $22.6 \%$ \\
\hline Italy & $15.1 \%$ & France & $17.9 \%$ & Luxembourg & $24.2 \%$ \\
\hline Turkey & $16.0 \%$ & UAE & $18.4 \%$ & Sweden & $25.8 \%$ \\
\hline Japan & $16.3 \%$ & Jordan & $18.5 \%$ & Estonia & $29.7 \%$ \\
\hline Source: IMF Database (International Financial Statistics). & & \\
\hline
\end{tabular}

Table 7: Performance of Banks: Non-Performing Loans to Total Loans

\begin{tabular}{|l|l|l|l|l|l|}
\hline Country & Ratio & Country & Ratio & Country & Ratio \\
\hline Korea & $0.5 \%$ & Saudi Arabia & $1.4 \%$ & Jordan & $4.5 \%$ \\
\hline Canada & $0.5 \%$ & Finland & $1.5 \%$ & Czech Rep. & $4.6 \%$ \\
\hline Switzerland & $0.7 \%$ & Germany & $1.7 \%$ & Lebanon & $4.9 \%$ \\
\hline Luxembourg & $0.8 \%$ & Chile & $1.9 \%$ & Spain & $5.4 \%$ \\
\hline Estonia & $0.9 \%$ & W. Bank \& Gaza & $2.2 \%$ & Latvia & $5.5 \%$ \\
\hline UK & $0.9 \%$ & Austria & $2.8 \%$ & UAE & $5.6 \%$ \\
\hline Australia & $0.9 \%$ & Turkey & $3.0 \%$ & India & $8.3 \%$ \\
\hline Sweden & $1.1 \%$ & Denmark & $3.1 \%$ & Italy & $16.5 \%$ \\
\hline USA & $1.3 \%$ & Belgium & $3.4 \%$ & Greece & $39.5 \%$ \\
\hline Japan & $1.4 \%$ & France & $3.6 \%$ & Cyprus & $45.5 \%$ \\
\hline
\end{tabular}

Table 8: Performance of Banks: Z-Scores

\begin{tabular}{|l|l|l|l|l|l|}
\hline Country & Ratio & Country & Ratio & Country & Ratio \\
\hline Greece & $5.6 \%$ & Sweden & $13.9 \%$ & Denmark & $20.6 \%$ \\
\hline Chile & $6.8 \%$ & Australia & $14.2 \%$ & Spain & $21.9 \%$ \\
\hline Estonia & $7.6 \%$ & Czech Rep. & $14.4 \%$ & Germany & $23.0 \%$ \\
\hline Turkey & $8.0 \%$ & Japan & $15.6 \%$ & Austria & $24.6 \%$ \\
\hline Cyprus & $10.3 \%$ & Switzerland & $16.2 \%$ & UAE & $26.8 \%$ \\
\hline Korea, Rep. & $10.4 \%$ & India & $17.4 \%$ & USA & $29.2 \%$ \\
\hline
\end{tabular}




\begin{tabular}{|l|l|l|l|l|l|}
\hline Finland & $11.0 \%$ & W. Bank \& Gaza & $17.7 \%$ & Lebanon & $32.7 \%$ \\
\hline UK & $11.4 \%$ & Saudi Arabia & $18.2 \%$ & Luxembourg & $41.7 \%$ \\
\hline Italy & $12.1 \%$ & France & $19.3 \%$ & Jordan & $50.0 \%$ \\
\hline \multicolumn{4}{|l}{ Source: IMF Database (International Financial Statistics). } \\
\hline
\end{tabular}

Table 9: Performance of Banks: Returns on Assets (ROA)

\begin{tabular}{|l|l|l|l|l|l|}
\hline Country & Ratio & Country & Ratio & Country & Ratio \\
\hline Greece & $-0.9 \%$ & Spain & $0.5 \%$ & Korea & $1.2 \%$ \\
\hline Cyprus & $-0.6 \%$ & Austria & $0.6 \%$ & Chile & $1.3 \%$ \\
\hline Italy & $0.1 \%$ & Finland & $0.6 \%$ & Latvia & $1.3 \%$ \\
\hline Switzerland & $0.3 \%$ & Belgium & $0.6 \%$ & UAE & $1.5 \%$ \\
\hline Japan & $0.3 \%$ & Denmark & $0.7 \%$ & W. Bank \& Gaza & $1.5 \%$ \\
\hline UK & $0.3 \%$ & Luxembourg & $0.7 \%$ & Turkey & $1.8 \%$ \\
\hline USA & $0.4 \%$ & Sweden & $0.9 \%$ & Saudi Arabia & $1.9 \%$ \\
\hline Germany & $0.4 \%$ & Canada & $1.1 \%$ & Estonia & $2.0 \%$ \\
\hline India & $0.4 \%$ & Czech Rep. & $1.2 \%$ & Jordan & $1.2 \%$ \\
\hline France & $0.4 \%$ & Lebanon & $1.2 \%$ & Australia & $1.1 \%$ \\
\hline Source: IMF Database & International Financial Statistics). & & \\
\hline
\end{tabular}

Based on the reported values in Tables 6-9 inclusive, we can state that the Jordanian banking system is relatively profitable (ROA) and maintains much lower probability of bankruptcy (Z-score) than other banking systems. In other words, licensed banks in Jordan are financially sound.

\section{THE DATA, METHODOLOGY AND EMPIRICAL RESULTS}

As mentioned in the introduction, this paper examines the impact of income diversification on the performance of Jordanian banks. Bank performance is measured by return on assets and net interest margin. The data that enters the empirical analyses includes all 13 licensed commercial banks, and covers the period 2009-2017. Foreign banks are not included in the analysis because of the unavailability of their financial statements. In addition, Islamic banks are also excluded from the analysis as they operate under different principle from commercial banks.

Based on the collected data, we estimate the following two seemingly unrelated regression models:

ROA $_{i, t}=\beta_{1}$ COM $_{i, t}+\beta_{2}$ RETAIL $_{i, t}+\beta_{3}$ SME $_{i, t}+\beta_{4}$ CORPORATE $_{i, t}+\beta_{5}$ RESTATE $_{i, t}+\beta_{6}$ BONDS $_{i, t}+\beta_{1}$ FED $_{i, t}+\beta_{2}$ TA $_{i, t}$

$+\beta_{3}$ EQUITY $_{i, t}+\beta_{4}$ EXPENSE $_{i, t}+\varepsilon_{i, t}$

$\mathrm{NIM}_{\mathrm{i}, \mathrm{t}}=\beta_{1} \mathrm{COM}_{\mathrm{i}, \mathrm{t}}+\beta_{2}$ RETAIL $_{i, t}+\beta_{3}$ SME $_{i, t}+\beta_{4}$ CORPORATE $_{i, t}+\beta_{5}$ RESTATE $_{i, t}+\beta_{6}$ BONDS $_{i, t}+\beta_{1}$ FED $_{i, t}+\beta_{2}$ TA $_{i, t}$

$+\beta_{3}$ EQUITY $_{i, t}+\beta_{4}$ EXPENSE $_{i, t}+\varepsilon_{i, t}$

where, the subscripts $i$ and $t$ denote banks $(i=1, \ldots, 13)$ and time $(t=1, \ldots, T=2009-2017)$ respectively.

The definitions of the dependent variables are as follows:

ROA $=$ Gross income divided by total assets (return on assets).

$\mathrm{NIM}=$ Net interest margin [Interest income - Interest expense] / Total assets.

The independent variables include the followings:

$\mathrm{COM}=$ Net commission income to total assets.

RETAIL = Proportion of bank credit to individuals to total credit.

$\mathrm{SME}=$ Proportion of bank credit to the SME sector to total credit.

CORPORATE $=$ Proportion of bank credit to the corporate sector to total credit.

RESTATE $=$ Proportion of bank credit to the real estate sector to total credit. 
BONDS = Proportion of bank investment in government bonds to total assets.

FED = Foreign exchange deposits to total deposits.

$\mathrm{TA}=$ natural logarithm of total assets.

EQUITY = Equity capital to total assets.

EXPENSE $=$ Total operating expenses to total assets.

In Table 10, we report some descriptive statistics for both the dependent and independent variables. These reported values reveal the following observations. First, during the period 2009-2017, the overall mean value of banks' ROA and NIM were equal to 1.8 percent and 3.1 percent respectively. In relative terms, net interest margin in Jordan is high. For example, this measure is equal to 0.8 percent in Luxemburg, 1.6 percent in Finland, and 2.9 percent in Germany (Kasman et al., 2014).

Second, our sample of bank reflect some significant variations in their respective credit to individuals, SMEs, corporate, real estate sector. For example, the maximum and minimum values of credit to the retail sector are equal to 54.3 percent and 1.1 percent respectively. This indicates that some banks have very limited exposure to the retail end of the credit market.

Third, our sample of banks differ in terms of their investments in government fixed-income securities (bonds). Again, while the overall mean value of this measure is equal 21.6 percent, its maximum and minimum values are equal to 36.6 percent and 0.2 percent respectively. These two values indicate that 36.6 percent of a bank's assets and 0.2 percent of another bank's assets are in the form of government securities respectively.

Fourth, it is important to note that the mean ratio of foreign exchange deposits to total deposits was equal to 27.4 percent. Whilst this proportion is high, it is not as high as that which prevails in, for example, Lebanon (more than 150 percent), and in Egypt (about 90 percent).

Table 10: Bank Performance: Descriptive Statistics

\begin{tabular}{|l|l|l|l|l|l|}
\hline Measure & MEAN & MEDIAN & MAXIMUM & MINIMUM & STD.DEV. \\
\hline ROA & 0.018 & 0.019 & 0.036 & -0.001 & 0.007 \\
\hline NIM & 0.031 & 0.030 & 0.044 & 0.015 & 0.006 \\
\hline COM & 0.007 & 0.006 & 0.020 & 0.002 & 0.003 \\
\hline RETAIL & 0.193 & 0.167 & 0.543 & 0.011 & 0.132 \\
\hline SME & 0.091 & 0.086 & 0.220 & 0.000 & 0.054 \\
\hline CORPORATE & 0.459 & 0.438 & 0.833 & 0.118 & 0.167 \\
\hline RESTATE & 0.143 & 0.146 & 0.303 & 0.014 & 0.056 \\
\hline BONDS & 0.216 & 0.212 & 0.366 & 0.002 & 0.071 \\
\hline FED & 0.274 & 0.277 & 0.649 & 0.006 & 0.115 \\
\hline TA & 21.353 & 21.335 & 23.976 & 19.435 & 1.009 \\
\hline EQUITY & 0.078 & 0.075 & 0.209 & 0.022 & 0.038 \\
\hline EXPENSE & 0.025 & 0.025 & 0.043 & 0.010 & 0.006 \\
\hline
\end{tabular}

ROA stands for gross income divided by total assets (return on assets). NIM is net interest margin [Interest income Interest expense] / total assets. COM is net commission income to total assets, RETAIL, SME, CORPORATE, and RESTATE stand for the proportion of bank credit to individuals, SME sector, corporate sector, and real estate sector to total credit respectively. BONDS is the proportion of bank investment in government bonds to total assets. FED stands for foreign exchange deposits to total deposits. TA is the natural logarithm of total assets. EQUITY is equity capital to total assets. EXPENSE is total operating expenses to total assets.

In addition, it is also useful to realize that return and assets reflected, on average, a downward trend. Indeed, this measure decreased from 2.254 percent in 2009 to 1.754 in 2013 and to 1.654 percent in 2017 (Figure 1). Net interest margin, on the other hand, was more stable. Again this measure was equal to 3.080 percent in 2009, 3.208 percent in 2013, and 3.139 percent in 2017 (Figure 1). 
Figure 1: Annual ROA and NIM

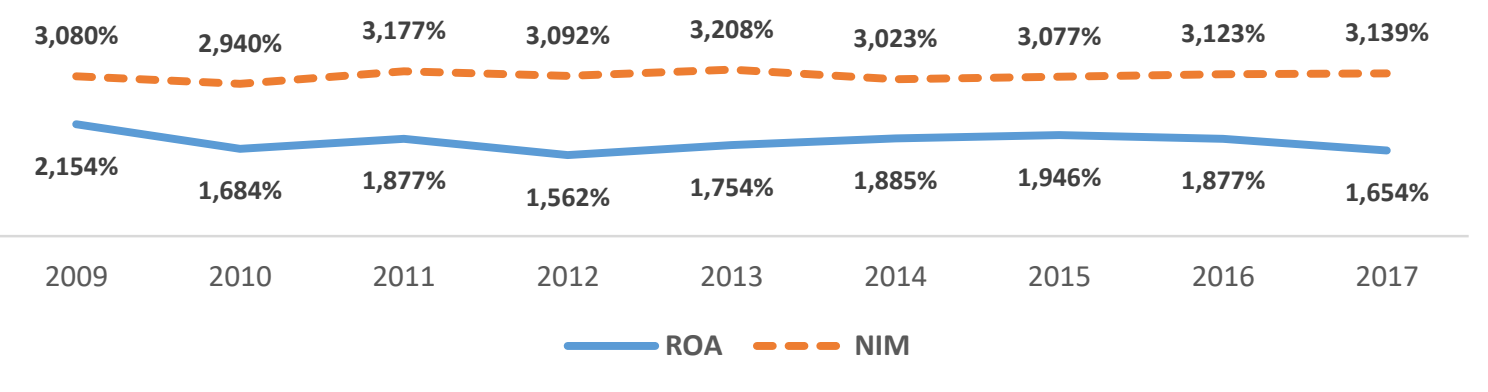

The estimation results of models 1 and 2 are reported in Tables 11-13 below. In Tables 11 and 12, we introduce each of the proxy measures of income diversification alone as possible determinants of ROA and NIM respectively. In Table 13, we introduce all the proxy measures of income diversification in the model. Again, based on the reported results, the following comments are provided.

First, banks that rely more on commission income achieve higher profits (ROA). However, this diversification aspect implies decreasing net interest income. The signs and magnitudes of these coefficients are equal to +0.446 and -291 respectively. These coefficients indicate that banks with more diversified sources of income pass on this "advantage" on to their customers by narrowing their net interest margins.

\section{Table 11: Regression Results: Return on Assets (ROA)}

\begin{tabular}{|l|l|l|l|l|l|l|l|}
\hline Variable & Coefficient & Coefficient & Coefficient & Coefficient & Coefficient & Coefficient & Coefficient \\
\hline TA & $0.001^{*}$ & $0.001^{*}$ & $0.001^{*}$ & $0.001^{*}$ & $0.001^{*}$ & $0.00^{*}$ & $0.001^{*}$ \\
\hline EQUITY & 0.005 & 0.002 & 0.020 & 0.012 & 0.004 & 0.017 & 0.010 \\
\hline EXPENSE & $-0.329^{*}$ & $-0.406^{*}$ & $-0.276^{*}$ & $-0.246^{*}$ & $-0.224^{*}$ & $-0.267^{*}$ & $-0.271^{*}$ \\
\hline COM & $0.446^{*}$ & --- & --- & --- & --- & --- & --- \\
\hline RETAIL & --- & $0.0256^{*}$ & --- & --- & --- & --- & --- \\
\hline SME & --- & --- & $-0.025^{*}$ & --- & --- & --- & --- \\
\hline CORPORATE & --- & --- & --- & -0.001 & --- & --- & --- \\
\hline RESTATE & --- & --- & --- & --- & $0.010^{*}$ & --- & --- \\
\hline BONDS & --- & --- & --- & --- & --- & $-0.002^{*}$ & --- \\
\hline FED & --- & --- & --- & --- & --- & --- & $0.0173^{*}$ \\
\hline Adj. R-Sq. & 0.573 & 0.687 & 0.598 & 0.585 & 0.678 & 0.580 & 0.767 \\
\hline F-Statistic & 52.940 & 85.883 & 58.500 & 55.615 & 82.328 & 54.312 & 128.292 \\
\hline D-W Stat. & 1.962 & 1.985 & 1.954 & 1.970 & 1.948 & 1.941 & 1.967 \\
\hline
\end{tabular}

ROA stands for gross income divided by total assets (return on assets). NIM is net interest margin [Interest income Interest expense] / total assets. TA is the natural logarithm of total assets. EQUITY is equity capital to total assets. EXPENSE is total operating expenses to total assets. COM is net commission income to total assets, RETAIL, SME, CORPORATE, and RESTATE stand for the proportion of bank credit to individuals, SME sector, corporate sector, and real estate sector to total credit respectively. BONDS is the proportion of bank investment in government bonds to total assets. FED stands for foreign exchange deposits to total deposits.

Table 12: Regression Results: Net Interest Income (NIM)

\begin{tabular}{|l|l|l|l|l|l|l|l|}
\hline Variable & Coefficient & Coefficient & Coefficient & Coefficient & Coefficient & Coefficient & Coefficient \\
\hline TA & $0.001^{*}$ & $0.001^{*}$ & $0.001^{*}$ & $0.001^{*}$ & $0.001^{*}$ & $0.001^{*}$ & $0.001^{*}$ \\
\hline EQUITY & 0.012 & -0.003 & 0.019 & 0.010 & -0.007 & 0.015 & 0.011 \\
\hline EXPENSE & $0.534^{*}$ & $0.380^{*}$ & $0.482^{*}$ & $0.483^{*}$ & $0.513^{*}$ & $0.495^{*}$ & $0.478^{*}$ \\
\hline COM & $-0.291^{*}$ & --- & --- & --- & -- & --- & --- \\
\hline RETAIL & --- & $0.018^{*}$ & --- & --- & --- & --- & -- \\
\hline SME & ---- & ---- & $-0.025^{*}$ & --- & --- & --- & --- \\
\hline
\end{tabular}




\begin{tabular}{|l|l|l|l|l|l|l|l|}
\hline CORPORATE & --- & --- & --- & 0.002 & -- & -- & -- \\
\hline RESTATE & --- & --- & --- & --- & $0.022^{*}$ & --- & --- \\
\hline BONDS & --- & --- & --- & --- & --- & -002 & --- \\
\hline FED & --- & --- & --- & --- & -- & $0.010^{*}$ \\
\hline Adj. R-Sq. & 0.891 & 0.847 & 0.851 & 0.853 & 0.921 & 0.847 & 0.853 \\
\hline F-Statistic & 315.813 & 214.458 & 223.384 & 225.041 & 450.903 & 215.409 & 225.586 \\
\hline D-W Stat. & 1.905 & 1.947 & 1.861 & 1.876 & 1.863 & 1.873 & 1.883 \\
\hline
\end{tabular}

NIM is net interest margin [Interest income - Interest expense] / total assets. TA is the natural logarithm of total assets. EQUITY is equity capital to total assets. EXPENSE is total operating expenses to total assets. COM is net commission income to total assets, RETAIL, SME, CORPORATE, and RESTATE stand for the proportion of bank credit to individuals, SME sector, corporate sector, and real estate sector to total credit respectively. BONDS is the proportion of bank investment in government bonds to total assets. FED stands for foreign exchange deposits to total deposits.

Second, the sign of the coefficient (RETAIL) is positive and significant in both model 1 and 2. Banks that lend more to the retail end of the market, earn wider net interest margins and greater profitability levels. This observation is due to two main reasons. First, banks require individuals to pay the interest expense of their borrowed funds up-front (from the beginning of the borrowing period). Secondly, due to the extra cost of dealing with individuals, banks that lend more to individuals tend to earn wider net interest margins.

Third, the sign of the coefficient (SME) is negative and significant when the dependent variable is bank profitability. Also, banks that lend more to the SME, earn narrower net interest margins. On average, this is due to the fact that the performance of this sector was poor during the period 2009-2017. Indeed, one can appreciate this observation from the total taxes paid to the treasury. This expense (taxes) has been a downward trend since 2009.

Fourth, the sign of the coefficient (CORPORATE) is not significant when the dependent variable is bank profitability or net interest margin. Again, this is due to the fact that the performance of this sector has been poor during the period 20092017. On average, this sector has been realizing accounting losses during the period 2009-2017.

Fifth, the sign of the coefficient (RESTATE) is positive and significant in both model 1 and 2 . Banks that lend more to finance real estate activities, earn wider net interest margins and greater profitability levels. This observation is due to two main reasons. First, banks require borrowers to pay higher interest rates on their borrowed funds. Secondly, due to the extra risk of this sector, banks that lend more to real estate activities tend to earn wider net interest margins.

Sixth, banks' investment in government securities (BONDS) negatively impacts their return on assets. This is expected given the relatively low interest rate on these assets. Within this context, it is important to note that in Jordan there is no secondary market for government securities. Banks are required by the Central Bank of Jordan to subscribe to these issues, and each bank is allocated a share of these issues according to its relative size. However, the fact that investing in government securities reduce banks' risk, this "benefit" is not shared with bank customers in the form of narrower net interest margin.

Seventh, the sign of the coefficient (FED) is positive and significant in both equations. Foreign exchange deposits impact bank profitability (ROA) in a positive manner. However, this positive impact comes at the expense of widening net interest margin. This result is what one would expect. Indeed, lending in foreign exchange incurs greater levels of risk, and hence the wider interest margin. In addition, the minimum reserve requirement on foreign exchange deposits is higher than that on local currency deposits.

Eighth, licensed banks in Jordan do benefit from economies of scale. The coefficient of bank size (SIZE) is consistently positive when the dependent variable is profitability. However, the sign of this coefficient is also consistently positive when the dependent variable is net interest margin.

Ninth, the impact of bank expenses on profitability is negative. However, this expense is passed-on to the customers in the form of wider net interest margin. These imply that while less efficient banks realize lower return on assets, they ask of their customers to pay for their inefficiencies by widening their net interest margins.

Finally, when we include all the proxy measures of income diversification in the models, the results do not really change (Table 13). Indeed, commission income, retail credit, SME credit, corporate credit, real estate credit, and bank investments in government securities do not change their signs and their significance. The same is also true for net interest margin. 
Table 13: Regression Results: Determinants of Bank Performance (ROA)

\begin{tabular}{|l|l|l|}
\hline Variable & ROA & NIM \\
\hline & Coefficient & Coefficient \\
\hline TA & $0.001^{*}$ & $0.001^{*}$ \\
\hline EQUITY & 0.003 & -0.014 \\
\hline EXPENSE & $-0.554^{*}$ & $0.319^{*}$ \\
\hline COM & $0.347^{*}$ & $-0.319^{*}$ \\
\hline RETAIL & $0.023^{*}$ & $0.023^{*}$ \\
\hline SME & $-0.028^{*}$ & $-0.027^{*}$ \\
\hline CORPORATE & 0.003 & $0.008^{*}$ \\
\hline RESTATE & $0.023^{*}$ & $0.022^{*}$ \\
\hline BONDS & $-0.009^{*}$ & $-0.016^{*}$ \\
\hline FED & $0.011^{*}$ & $0.008^{*}$ \\
\hline Adj. R-Squared & 0.770 & 0.954 \\
\hline F-Statistic & 44.132 & 268.808 \\
\hline D-W Statistic & 1.901 & 1.941 \\
\hline
\end{tabular}

ROA stands for gross income divided by total assets (return on assets). NIM is net interest margin [Interest income Interest expense] / total assets. TA is the natural logarithm of total assets. EQUITY is equity capital to total assets. EXPENSE is total operating expenses to total assets. COM is net commission income to total assets, RETAIL, SME, CORPORATE, and RESTATE stand for the proportion of bank credit to individuals, SME sector, corporate sector, and real estate sector to total credit respectively. BONDS is the proportion of bank investment in government bonds to total assets. FED stands for foreign exchange deposits to total deposits.

\section{SUMMARY AND CONCLUSIONS}

Given that finance is important, the financial economics literature contains numerous papers that examine various aspects related to financial development. One of these aspects is the determinants of bank performance in terms of their profitability and net interest margin (cost of intermediation). This paper examined the Jordanian banking sector in terms of one major issue: (1) The impact of income diversification on the performance licensed Jordanian commercial banks over the period 2009-2017. The empirical results indicate a number of observations and conclusions. Some of these are briefly outlined below. First, net commission income is the dominant factor in affecting bank profitability and net interest margin. The coefficients of this variable are equal to +0.347 and -0.319 respectively. Second, retail lending is also significant (statistically and extent) in affecting bank performance (positively) and cost on intermediation (positively). Based on the results of this paper, the implications are clear. It is in the interest of the banking system in Jordan to promote financial inclusion at the national level. Indeed, this aspect is important to, not only the concerned individuals, but also to their (banks) performance. Moreover, with greater levels of financial inclusion, net interest margin might also narrow. 


\section{REFERENCES}

Adzobu, L., Elipkimi, A., Agbloyor, K., Aboagye. (2017). The effect of loan portfolio diversification on banks' risks and return: Evidence from an emerging market. Managerial Finance. 43: 1274-1291.

Allen, L. (1988). The determinants of bank interest margins: A note. Journal of Financial and Quantitative Analysis. 23(2): pp. 231-235.

Almarzoqi, R., Naceur, S. B. (2015). Determinants of bank interest margins in the Caucasus and Central Asia. IMF Working Paper No. $15 / 87$.

Angbazo, L. (1997). Commercial bank net interest margins, default risk, interest rate risk and off balance sheet banking. Journal of Banking and Finance. 21: 55-87.

Bagehot, W. (1873). Lombard Street, Homewood, IL: R. Irwin 1962 edition.

Berger, A., Hasan, I., Zhou, M. (2010). The effects of focus versus diversification on bank performance: Evidence from Chinese banks. Journal of Banking and Finance. 34: 1417-35.

Boyd, J., Graham, S., Hewitt, R. (1993). Bank holding company mergers with nonbank financial firms: Effects on the risk of failure. Journal of Banking and Finance. 17: 43-63.

Catao, L., Terrones. (2016). Financial de-dollarization: A global perspective and the Peruvian experience. IMF Working Paper 16/97.

Chiorazzo, V., Milani, C., Salvini, F. (2008). Income diversification and bank performance: Evidence from Italian banks. Journal of Financial Services Research. 33: 181-203.

Adzobu, L., Agbloyor, E., Aboagye, A. (2017). The effect of loan portfolio diversification on banks' risks and return: evidence from an emerging market. Managerial Finance. 1-23.

Elsas, R., Hackethal, A., Holzhäuser, M. (2010). The anatomy of bank diversification. Journal of Banking and Finance. 34: $1274-87$.

Hashem, H. (2016). Determinants of Egyptian banking sector profitability: Time series analysis from 2004-2014. International Journal of Business and Economic Sciences Applied Research. 9: 73-78.

Helhel, Y. (2015). Evaluating the performance of the commercial banks in Georgia. Research Journal of Finance and Accounting. 5: $146-156$.

Ho, T., Saunders, A. (1981). The determinants of bank interest margins: Theory and empirical evidence. Journal of Financial Quantitative Analysis. 16: 581-600.

Jima, M. (2018). Determinants of net interest margin in the Ethiopian banking industry. Journal of Finance and Economics. 5: 96-104.

Klein, P., Saidenberg, M. (1997). Diversification, organization and efficiency: Evidence from bank holding companies. Working Paper No. 97/27, Philadelphia: Wharton School Center for Financial Institutions.

Kohlscheen, E., Murcia, A., Contreras, J. (2018). Determinants of bank profitability in emerging markets. Bank for International Settlements Working Paper No. 686.

Levine, R. (1997). Financial development and economic growth: Views and agenda. Journal of Economic Literature. XXXV: 688-726.

Lucas, R. (1988). On the mechanics of economic development. Journal of Monetary Economics. 22: 3- 42.

Maudos, J. (2017). Income structure, profitability and risk in the European banking sector: The impact of the crisis. Research in International Business and Finance .39: 85-101.

Nassar, K., Martinez, E., Pineda, A. (2015). Determinants of banks' net interest margins in Honduras. IMF Working Paper No. 14/163.

Nisar, S., Peng, K., Wang, S., Ashraf, B. (2018). The impact of revenue diversification on bank profitability and stability: Empirical evidence from South Asian countries. Internal Journal of Financial Studies. 6: 1-25.

Olarewaju, O., Migiro, S., Sibanda, M. (2017). Operational diversification and financial performance of Sub-Saharan Africa commercial banks: Static and dynamic approach. Economica. 13: 84-106.

Robinson, J. (1952). The generalization of the general theory, in the rate of interest and other essays. MacMillan, London, UK. 